\title{
A Shifting and Convoluted Paradigm in the Regime of Crime Control, Due Process and Penal Justice
}

\author{
Abubakar Bukar Kagu \\ Senior Lecturer, Faculty of Law, Yobe State University, Nigeria and Director, CRCDHS, YS Univ.
}

\begin{abstract}
The well-known criminal justice constituencies of crime control, due process and penal sentence are facing far reaching transformations resulting in some paradoxical outcomes that include an upsurge in populist legislations and the emergence of non-state actors in justice administration. Although these may be reflections of criminal justice's attempt to enhance effectiveness, the outcome has been severely convoluted that the question of rights and even the foundation of theory of social contract are waning into the shadows of bureaucratic policies and practices that seemed to threaten the fabric of justice administration. This paper is an attempt to show how criminal justice policies and strategies are gravitating from their orthodox constituency to a territory that is mixed in populism, punitivism as well as the compounded regime of coalitions of public and private actors defined mostly by contentious new practices of crime control, procedural changes and an economic way of thinking, leading to unconventional and often controversial practices.
\end{abstract}

Keywords: Criminal, Transformation, Justice, Economic, Public

DOI: $10.7176 / \mathrm{JLPG} / 88-04$

Publication date: August $31^{\text {st }} 2019$

\subsection{Introduction}

In socio-legal literature, the concept of criminal justice and what it intends to achieve has always been a contentious and changing phenomenon (Foucault, 1975; Shapiro, 1986; Garland, 1991: 2002; Ashworth, 2002; Samaha, 2005). The history of dynamic constituency of social contract has continued to develop in a climate that is filled with multifaceted relationships between "criminal justice, social order and the State" (Uglow, 1984: 75). Amidst this came the growing pessimism in the ability of the institution of criminal justice's to actually control crime or even reduce recidivism. Hence, the constant, often populist exaggeration on the need for tougher measures which is now leading to superficial analysis and punitive standpoints on how to deal with crimes and social disorder (Feeley, 1982: 388), leading to wavering practices that are not always rational (Burke, 2012: 3).

From the last quarter of the $21^{\text {st }}$ century, debate on the three prominent constituencies of criminal justice has seen the proliferation of new ideals and actors. The field of crime control, dues process and penal sentence have transformed, especially with the growing populist and punitive legislations, the emergence of non-state actors in the field of crime control and indeed the proliferation of inconsistent practices such as plea bargaining. By far, these are a reflection of the unstable history of criminal justice reforms and policies that have now led to series of questions of the whole idea of justice and the rule of law.

\subsection{A Paradigm Shift in Policy and Strategy}

The intricates of the growing complex paradigm in criminal justice policies and strategies has, no doubt resulted in severe institutional and policy contours. In many cases, the justice system was seen to gravitate towards a new direction in ideas that are historically within the exclusive prerogative of the state such as crime prevention and even prisons are now shared by both public and private sectors (Garland, 2001: 176), while the correctionalistic optimism that emerged with ideas such as rehabilitation seemed to be disappearing into the shadows. Hence, the contention that criminal justice has become a compounded regime of coalitions of public and private actors (Burke, 2012: 117). This justifies the argument that the institution of criminal justice, today, is more of an embodiment of a reworked conception defined by a new criminology of control, and an economic thinking in both the key areas of policy and practice (Garland, 2001: 3). Unsurprisingly, these structural transformations are driven by many factors, including the admission, in many jurisdictions of how every criminal justice strategy has failed to stop crime (ibid: 106-175). The outcome of this pessimistic view has, to a larger extent led to a reworked pattern and emotional sensibility that now drives crime control agencies to invoke alternatives that are often controversial such as the increased use of new methods of surveillance and violations of privacy as well as the emphasis on containment of incivility; all in the facade that the system must ensure safety and security (Burke, 2012: 201-202). In the end, the society becomes subjected to policies and situations that legitimise compromises and breaches of the ideals that the justice system was meant to protect in the first place. In theory, one of the most popular models of criminal justice proffered by Bottoms and McClean (1976) referred to as "liberal bureaucratic model" insists that the overriding function of criminal justice should not be the repression of criminal behaviour but the protection of individual liberty as well as the rights of the defendant. For that system to work, however, such protections must have limits and should not be allowed to be used frivolously 
(Ibid: 229).

Concerned about this political adventurism that continue to resonate in the justice system, proponents of procedural rights and civil liberties have become incessantly agitated, insisting that the field of justice administration must reclaim its status and ideals of protection of the citizen from impunity. This they argue is because insistence on crime control without recourse to the principality of due process only leads to an aggressive and belligerent policing. They argue that emphasis on due process is a key component of justice and the most potent safeguard restraints the excesses of officials, ensure the protection of individual rights, privacy and liberty.

\subsection{Crime Control}

As a model, crime control is mainly based on the proposition that the society must take stringent measures to protect the community from criminals. Although this approach is sometimes characterised by elements of repressiveness, the arguments for it are often sentimentally compelling. What has become of great concern in contemporary legal scholarships is the way this approach has steadily become synonymous with practices that are aggressive and even oppressive. In many regimes, the strategy to fight crime at all cost has culminated in a relaxed concern for civil liberties and the rights of offenders (Garland, 2001: 12). Also, there appears to be a gravitation towards an 'actuarial' approach that is characterised by intrusions on people and communities based on the sentiment and label of risk (Burke, 2012: 203). Examples of these can be found in motivations and practices such as preventive detention, mass surveillance and offender profiling (ibid). There is also the increasing attitude among crime control agencies in classifying and managing individuals or groups on the perception that they are a community who pose a greater risk or threat to the society (Feeley and Simons, 1994: 180). Wilson, for instance, argues:

"Wicked people exist; nothing avails except to set them apart from the innocent people. And many people, neither wicked nor innocent, but watchful, dissembling, and calculating of their chances, ponder our reaction to wickedness as a clue to what they might profitably do" (cited in Siegel, 2009: 24).

While concern for civil liberties continue to grow, proponents of crime control argue that the public is always outraged by the conduct of criminals and therefore the legitimacy for an efficient and aggressive policing as well as tough sanctions (ibid: 24). They also insist that in the cause of crime prevention, it is justifiable to surrender certain individual rights for the collective good the whole community (ibid). For example, they argue that for the system to be effective, crime control agencies must be granted unhindered powers to embark upon patrols, surveillance, search and seizure, without the fear of any consequence of liability or charge (ibid).

These propositions resonate with the current highly charged political environment that accentuates the need for harsher penalty for offenders, which according to Garland (2001) has turned government policy on crime more 'populist' and sentimental rather than rational opinions and advice of experts and practitioners. In order to assuage public concerns and gain political leverage, politicians have become used to making constant reference to the 'victim', the weak and the vulnerable (ibid: 173). The effect of this has been the crude politicisation of crime control policies, leading to the complexity that is now inherent in the structure of the relationship between policy decisions, legislation and judicial reforms that promote punitive dogma as against the insistence that the justice system should maintain fairness and reasoning (ibid). Another aspect that is of great concern to scholars is that the 'crime control model' tends to challenge the values of 'process rights', as it sometimes reject painstaking judicial scrutiny associated with adversarial processes, on the bases that such scrutiny accord the guilty an undeserved opportunity to escape liability, thereby undermining the criminal justice system and making it appear unreliable in the protection of the victim and the society (Sanders and Young, 1994: 14). As McBarnet opined:

"a wide range of prosecution evidence can be legally produced and presented, despite the rhetoric of a system geared overwhelmingly to safeguard the accused, precisely because legal structure, legal procedure, legal rulings, not legal rhetoric, govern the legitimate practice of criminal justice, and there is quite simply a distinct gap between the substance and the ideology of the law". (1985: 155).

Other proponents of the crime control model suggest that the augmentation of policing institutions and an intensified surveillance strategy play a significant role in crime prevention (Goffredson and Hirschi, 1990: 270: Klockars and Mastrofski, 1991: 537). It I however, important to note that many of these claims are dominated by a policing tactics by which target groups chosen in ways that promote a generalised judgement (Sherman, 1992: 7-9). Hence, the society finds itself engulfed in stereotyping certain groups or communities.

\subsection{Due Process}

Unlike the emphasis of the crime control model for tougher and unhindered policing and conviction, the 'due process' model underscores the primacy of the rights of the individual and the limit of official powers (Sanders and Young, 1994: 16). This idea is firmly rooted in the broader conceptual framework of criminal justice's jurisprudential compliance, which can be traced to the root of the social contract theory. Proponents of due 
process maintain that the legitimacy of policing and the justice system is reliant on how much of the citizen's rights of citizens is protected and the assurance that law enforcement agents can be held to account where they err (McCoville, 1998). Hence, any belligerence in crime control policies or strategies that subvert rights and civil liberties cannot be equated with fairness or democratic values. Some scholars also caution that due to the enormous powers of agencies of the State, the process of law enforcement must be cautious and guarded from any antagonism that may lead to indiscriminate arrests, coerciveness and any impropriety that will lead to breach of the rights of citizens or even to the conviction of the innocent (Sanders and Young, 1994: 16).

Most of the proponents of 'due process' do not believe, as Wilson (1975) does, that individuals are innately inclined to commit crime. Rather, they consider the individual as a victim of a dynamic social structure and his criminal behaviour may, sometimes be the result of overwhelming social or psychological intricacies. Hence, no matter the sentiment about offenders, the community must first ensure that rights are protected from repressive behaviour of crime control agencies. In fact, the society is more protected and at ease from crime if the State gives emphasis to the basic needs of the people and not hardcore and brutal crime control approaches. Even the record rate of recidivism can be reduced through liberal measure such as restorative justice (Siegel, 2009: 26-29). Despite the common theoretical dichotomy between the crime control and the due process, criminal justice system is in practice characterised by both models, which operate together as part of an integral process. icch

\subsection{Penal Justice}

The idea of punishment has always been a distinctive hallmark of criminal justice since time immemorial (Zedner, 2004: 71). This act of subjecting an individual to some kind of pain, embarrassment or ridicule was anthropologically discovered to be part of human social relations long before the advent of what we today know as a bureaucratic society with an organised police force, and a hierarchical court and prison system (Zedner, 2004: 71). Describing what punishment is, von Hirsch (1985) qualified it as an aspect of justice that serves as a censure and a means of conveying a message of blame to the offender, making him accountable for his wrongdoings. It is that measure of deterrence that threatens the individual with penal deprivation that expresses the 'censure' and serves as a prudential disincentive that deters crime. Although Hirsch thinks deterrence alone is not a sufficient reason for punishment, he maintains that it is necessary (Hirsch, cited in Bagaric 2001: 67). The most common classification of punishment by scholars are 'retributivism' which sees punishment as an end objective and believe everyman should be punished adequately for his crime, and 'Utilitarianism', which on the other hand is concerned with the future effects of punishment and therefore demands that punishment should be a means of achieving some wider and future societal objective (Hudson, 2004: 3-4). These groupings were represented by the popular theories of 'retribution' proposed by Kant (1724-1804) and those of Utilitarianism as expressed by Bentham (1748-1832) and Mill (1806-1873). While these two approaches remain the most common reasons and responses, it is unclear whether any of the two is effective in controlling or even reducing crime.

In modern day criminal justice, punishment is mainly imposed upon a decision that stems from the authority of the State. For any suffering to be a 'punishment' it must be inflicted by those who have authority to do so (Easton and Piper, 2012: 4). Murphy (1970) explains the idea of punishment form the Kantian perspective retributivism which suggests that if the law is to remain fair and just, it is important to guarantee that offenders not gain an unfair advantage over those who do obey the law. Thus, and so punishment should be there to maintain a proper and legitimate balance between benefit and obedience.

Although penal justice is arguably the most common response to crime (Clarkson, 2005: 6), there is little empirical evidence to suggests that it actually stops crime or reform the offender (Marsh, et al. 2004: 6). And of all the processes involved in the administration of justice, none is more controversial and neither has suffered vehement criticism as the idea, process and purpose of punishment (Golding, 1974: 69). Custodial sentence, which is the most common form of criminal sentence in many parts of the world has failed to serve the goals of crime control or even the ideals of corrective justice. Hence, retribution is more about blameworthiness and culpability (Golding, 1974: 84), with an origin that is linked to the Roman 'Lex Talionis' (Zedner, 2004: 86). That was among the reasons why it continued to attract a great deal of scholarly debates and its operation is seen to have lately resonated in the form of 'just desert' (ibid.). The difference between 'retribution' and 'desert' however, is that the former sees punishment from the point of morality in that every offender deserves to be punished for his action, while the latter encourages punishment but emphasises that such punishment must be proportionate to the crime committed (Burke, 2012: 165-166). The debate on 'proportionality' has remained at the heart of criticism of the idea of 'just desert'. Critics of 'desert' such as Easton and Piper (2012) argue that it is impossible to have a justice system in which every offender would be sentenced to a different form or degree of punishment believed to be exclusively proportionate to his offence, as this would invariably result in as many types of punishment as there are offenders and will make the system of punishment quite complex and inconsistent.

Another famous theory in penal justice is the utilitarian theory, which views punishment as a means to 
achieving an end, suggesting that punishment, or the fear of it is a measure in the deterrence of crime. Utilitarian ideologists view the offender as part of the larger society whose actions and omissions are inherently influenced by social factors and not just the simple impulse to commit crime. They criticise the retributivists approach as an oppressive culture that paves the way for punitive policies, which they associate with reactionary States (ibid: 99). Other scholars also maintain that the essence and justification for punishment should be in its capacity to either deter the offender and the wider public, rehabilitate the offender or incapacitate those in incarceration from committing further offence (Ten, 1987: 74), and that the core objective of punishment must be evaluated in terms of its consequences and rationality (Burke, 2012: 149).

As compelling as it sounds, utilitarian ideology has also been sharply criticised as lacking in the protection of the rights of the individual. Some core champions of 'social utility' dismisses the issue of rights as a "mischievous" maintaining that 'rights' are short of value in resolving ethical, social and political problems, because 'rights' are seen as impossible to construe (Easton and Piper, 2012: 128). Countering this criticism was the assertion that utilitarianism cannot be wholly condemned as a concept that opposes rights, in as much as we understand that rights promote utility (Baggarric, 2001).

Attempting to find an alternative approach for both the retributivist and utilitarian ideals, Braithwaite and Petit (1993) formulated a new theory based on what they term as the 'consequential theory of justice'. According to this theory, punishment should be meant to serve some future objective but unlike traditional utilitarianism, the individual is to be regarded as a 'person' and not as a means of achieving some wider objective. Von Hirch however dismisses this theory, arguing that its propositions are even more complicated than the traditional utilitarianism, because it makes it even harder to devise a scale of punishment (von Hirch,2005 cited in Easton and Piper, 2012: 129).

It is obvious however that both theories do not oppose the operation of punishment as a tool in justice administration; they only diverge on the questions of form, purpose and consequence. Looking at the practical penal practices of legal regimes across the world, it is noticeable that both the utilitarian objectives and the retributivist goal have co-existed simultaneously, whereas it is their relevance in both law and practice that keeps changing.

Although many of the earliest penal codes across the world were characterised by few codified laws and a justice system predicated on the arbitrary application of highly punitive sentences (Foucault, 1977: 3). Although some argue that harsh exercise of justice has declined, at least in most societies, and has been modified by rightsbased adversarity, the rule of law and other values such as reparation and rehabilitation (Zehr, 1990; Wachtel and McCold, 2001; Hudson, 2004). Yet, there is a growing scepticism among scholars over these new penological developments, even in western democracies, on the ground that the criminal justice system is witnessing a paradigm reversal towards retributivism (Garland, 2001; Zedner, 2004). This is seen to be a reflection of the decline in rehabilitative ideals, and the emergence of 'labelling theory' alongside the 'victimised actor model' of crime and criminal behaviour, both of which are based on the notion that treatment and intervention are more likely to produce rather than reduce criminal behaviour (Burke, 2012: 161). Secondly, he argues, the increase in crime rates and disturbances in prisons further compound doubts about the capability of the State to tackle these problems and lastly the need by governments to reduce public expenditure in the administration of criminal justice (Ibid: 161). Commenting with regards to these types of complexities, Garland states that:

"The modern institutions of punishment are especially prone to conflicts and tensions that tend to undermine their effectiveness and legitimacy as instruments of social policy. These conflicts -between condemnation and forgiveness, vengeance and mercy, the sanctity of the law and the humanity of compassion, social defence and individual rights, the urge to exclude and the dream of rehabilitationset up complex, ambivalent sentiments that colour the day-to-day experience of those caught up in the penal relations, whether as administrators and officers, inmates and clients, or as members of the public in whose name penal sanctions are nowadays imposed" (1999: 2).

While punishment is still a common phenomenon in almost every criminal justice regime, it is yet to establish that it actually does deter crime or to respond to the accusation that it as a tool of repression and subordination used by the dominant class to sustain power interests (Zedner, 2004: 79). The 'diverting function' theory for instance, maintains that among the many functions of punishments, particularly imprisonment, is a class-based alienation and containment of a particular group or section of the society, because it mainly focuses on narrow band of offences such as personal violence and petty property offences ignoring other greater social offences that often emanate from the act powerful individuals and corporations (Cavadinho and Dignan, 1997).

\subsection{Conclusion}

Practical trajectories of criminal justice in contemporary society have significantly redefined the nature and characteristic of crime control, due process and penal justice. Evidently, ideas such as rehabilitation no longer possess great relevance in criminal justice policies. Instead, criminal justice ideals are now focused more on containment and on depicting offenders as a culpable individual deserving of punishment. The series of reforms 
occurring in the institution of criminal justice are essentially leading to far reaching changes in the nature and narratives of what and how to deal with crimes and offenders. The deep gravitation towards control and penal populism poses the danger that crimes can be convicted without sufficient mens rea. Hence, even genuine culpability becomes hard to determine.

One of the complex transformation in criminal justice is the expansion of private actor participation. The advent of private prisons, private surveillance and even parole officers has tremendously diluted the institution of criminal justice to the point that the system becomes commodified by profit-oriented partners and driven by economic way of thinking, which risks degenerating into a ridiculous system where crime will essentially be seen as not only a danger to the society but also a means of profit. This fragile process in which the orthodox role of the State is shared with private actors is a model that diminishes confidence on the neutrality and fairness of criminal justice. Displacing the core state agencies such as the police from crime prevention and protection of the citizenry is both a controversial and delicate contour that raises more questions on the legitimacy of the state and also shakes the very foundation of the idea of social contract. It also creates a tension on whether criminal justice strategies will, henceforth allow for fair and transparent exercise of powers.

\section{References}

1. Ashworth, A. (1998). The Criminal process: an evaluative study. Oxford: Oxford University Press.

2. Ashworth, A. (1998). The Impact on Criminal Justice, in B. Markensis (Ed.) The Impact of the Human Rights Bill on English Law.

3. Ashworth, A. (2010). Sentencing and Criminal Justice. Cambridge: Cambridge University Press.

4. Bayley, D. (2001). 'Security and Justice for All', in H. Strang and J. Braithwaite (Eds.), Restorative Justice and Civil Society. Cambridge: Cambridge University Press.

5. Bottoms, A. E., and McClean J. D. (1976). Defendants in the Criminal Process. Routledge.

6. Burke, R. H. (2011). Criminal Justice Theory: An Introduction. Routledge.

7. Cavadinho, M., and Dignan, J. (1997). Reparation, Retribution and Rights, International Review of Victimology, 4, 233-253.

8. Easton, S., and Piper, C. (2012). Sentencing and Punishment: The Quest for Justice. Oxford: Oxford University Press.

9. Feeley, M. M., (1979). Perspectives on plea bargaining. Law and Society Review. 13(2), 199-209.

10. Feeley, M., and Simmons, J. (1994). Actuarial Justice: The emerging New Criminal Law, in Nelken, D., (Ed.) Futures of Criminology. London: Sage.

11. Foucault, M. (1977). Discipline and Punish. London: Allen Lane.

12. Garland, D. (1999), Editorial: Punishment and Society Today. Punishment and Society, 5-10.

13. Garland, D. (2001). The Culture of Control: Crime and Social Order in Contemporary Society. Oxford: Oxford University Press.

14. Golding, M. P. (1974). Philosophy of Law. Prentice-Hall.

15. Klockars, C. B., and Mastrofski, S. (1991). Thinking about Police. New York: McGraw-Hill.

16. McBarnet, D. J. (1985). Conviction: Law, the State and the Construction of Justice. London: Macmillan Publishers.

17. McConville, M. (1998). Plea Bargainings: Ethics and Politics. Journal of Law and Society, 25(4), 562-587.

18. McConville, M., and Mirsky, C. L. (2005). Jury Trials and Plea Bargaining: A True History, Portland: Hart Publication.

19. Samaha, J. (2005). Criminal Justice with Infotrac. Cengage Learning.

20. Sanders, A., and Young, R. P. (1994). Criminal Justice. Butterworths.

21. Sanders, A., Hoyle, C., Morgan, R. And Cape, E. (2001). Victim Impact Statements: Can't Work, Won’t Work. Criminal Law Review, pp. 447-458.

22. Sanders, A., Young, R., and Burton, M. (2010). Criminal Justice (4th ed.). Oxford University Press.

23. Shapiro, M. (1986). Courts: A Comparative and Political Analysis. University of Chicago Press.

24. Siegel, L. J. (2009). Introduction to Criminal Justice. Cengage Learning.

25. Uglow, S., Dickson, L., Cheney, D., and Doolin, K. (2002). Criminal justice. London: Sweet and Maxwell.

26. Von Hirsch, A. (1993). Censure and Sanctions. Oxford: Oxford University Press.

27. Zedner, L. (2004). Criminal Justice. Oxford: Oxford University Press.

28. Zedner, L. (2006). Policing Before and After the Police the Historical Antecedents of Contemporary Crime Control. British Journal of criminology, 46(1), 78-96. 